\title{
Analisis Unsur-Unsur Pendidikan Masa Lalu Sebagai Dasar Penentuan Arah Kebijakan Pembelajaran Pada Era Globalisasi
}

\author{
Ni Luh Gede Erni Sulindawati ${ }^{*}$
}

${ }^{1}$ Jurusan Akuntansi, Universitas Pendidikan Ganesha, Singaraja, Indonesia

\section{A R T I C L E I N F O}

\section{Article history:}

Received 26 Juni 2018

Accepted 28 Juni 2018

Available online 30 Juni 2018

Kata Kunci:

Pendidikan; Kebijakan

Pembelajaran; Era

Globalisasi

Keywords:

Education; Education

Policy; Globalization Era

\begin{abstract}
A B S T R A K
Artikel ini bertujuan untuk menganalisis unsur-unsur pendidikan yang sudah diterapkan dan permasalahan yang dihadapi pada masa lalu, serta penentuan dasar kebijakan pendidikan yang diterapkan pada era globalisasi. Unsur-unsur pendidikan pada masa lalu terus-menurus diupayakan perbaikan dan penyempurnaan ke arah yang lebih baik. Dasar kebijakan pendidikan yang dapat diterapkan pada masa depan antara lain (1) transformasi Pendidikan sekolah menuju Abad XX1, (2) perlu memahami makna pentingnya modernisasi dan modernitas, (3) kehidupan modern yang penuh dengan berbagai ketimpangan, pertentangan, dan kemajuan dapat membuat manusia kehilangan maknanya dalam hidup, untuk menghindari hal ini dianjurkan suatu program pendidikan umum yang memberikan kemampuan kepada siswa untuk menangkap berbagai jenis makna yang terdapat dalam pendidikan, dan (4) peserta didik perlu lebih ditekankan pendidikan sejarah, sejarah adalah suatu pelajaran yang diberikan kepada para siswa untuk
\end{abstract} memahami mengapa suatu masyarakat dalam waktu tertentu di masa lampau mengambil keputusan tertentu dalam menghadapi persoalan tertentu. Para siswa secara berangsur-angsur dibimbing untuk menangkap makna apa yang terdapat dibalik yang terlihat atau terasa secara fisik, para siswa dilatih untuk memahami makna dari makna yang kecil sampai makna yang besar yaitu makna kehidupan itu sendiri.

\begin{abstract}
A B S T R A C T
This article aims to analyze the elements of education that have been applied and problems encountered in the past, as well as determining the basis of educational policies that are applied in the globalization era. Elements of education in the past continuously strived for improvement and improvement to a better direction. Basic education policies that can be applied in the future include (1) the transformation of school education to the XX1 century, (2) need to understand the significance of modernization and modernity, (3) modern life filled with inequalities, contradictions and progress can make human lose its meaning in life, to avoid this it is recommended a general education program that gives students the ability to capture the various types of meaning contained in education, and (4) learners need more emphasis on historical education, history is a lesson given to the students to understand why a society in a given time in the past took a certain decision in the face of a particular problem. Students are gradually guided to grasp the meaning of what is behind the visible or physically felt, the students are trained to understand the meaning of the small meaning to the great meaning of the meaning of life itself.
\end{abstract}

\footnotetext{
* Corresponding author.

E-mail addresses: luhgedees1969@gmail.com
} 


\section{Pendahuluan}

Pendahuluan Dunia pendidikan dewasa ini di Indonesia mengalami guncangan. Guncangan tersebut bukan disebabkan oleh kehebatan mutu pendidikan nasional tetapi lebih banyak disebabkan karena kesadaran akan bahaya keterbelakangan pendidikan di Indonesia. Perasaan ini disebabkan karena beberapa hal yang mendasar. Salah satunya adalah memasuki abad ke- 21 gelombang globalisasi dirasakan kuat dan terbuka. Kemajaun teknologi dan perubahan yang terjadi memberikan kesadaran baru bahwa Indonesia tidak lagi berdiri sendiri. Indonesia berada di tengah-tengah dunia yang baru, dunia terbuka sehingga orang bebas membandingkan kehidupan dengan negara lain. Yang kita rasakan sekarang adalah adanya ketertinggalan didalam mutu pendidikan. Baik pendidikan formal maupun informal. Dan hasil itu diperoleh setelah kita membandingkannya dengan negara lain. Pendidikan memang telah menjadi penopang dalam meningkatkan sumber daya manusia Indonesia untuk pembangunan bangsa. Oleh karena itu, kita seharusnya dapat meningkatkan sumber daya manusia Indonesia yang tidak kalah bersaing dengan sumber daya manusia di negara-negara lain.

Kualitas pendidikan Indonesia yang rendah itu juga ditunjukkan data Balitbang tahun 2003 bahwa dari 146.052 SD di Indonesia ternyata hanya delapan sekolah saja yang mendapat pengakuan dunia dalam kategori The Primary Years Program (PYP). Dari 20.918 SMP di Indonesia ternyata juga hanya delapan sekolah yang mendapat pengakuan dunia dalam kategori The Middle Years Program (MYP) dan dari 8.036 SMA ternyata hanya tujuh sekolah saja yang mendapat pengakuan dunia dalam kategori The Diploma Program (DP).

Menurut Zaifbio (2010) penyebab rendahnya mutu pendidikan di Indonesia antara lain adalah masalah efektifitas, efisiensi dan standardisasi pengajaran. Hal tersebut masih menjadi masalah pendidikan di Indonesia pada umumnya. Di samping itu dunia pendidikan haruslah mampu menghadapi tantangan abad XXI (globalisasi) yaitu dunia ilmu dan pengetahuan. Ada berbagai pandangan mengenai corak kehidupan abad XXI (yang akan datang). Menurut Danniel Bell (dalam, Bochouri, 2001) kehidupan dalam masa mendatang akan ditandai oleh dua kecendrungan yang saling bertentangan yaitu kecendrungan untuk berintegrasi dalam kehidupan ekonomi dan kecendrungan untuk berpecah belah (kecendrungan Fragmentasi) dalam kehidupan politik. Kedua kencendrungan ini sudah menjadi kenyataan diberbagai kawasan di dunia ini. Integrasi ekonomi telah terjadi di Eropa, di asia pasific dan di asia tenggara. Fragmentasi politik juga terjadi dimana-mana. Kekuatan yang paling potensial untuk menimbulkan fagmentasi politik adalah etnisitas. Salah satu arti globalisasi adalah bahwa masalah-masalah tertentu seperti masalah pertumbuhan penduduk, masalah lingkungan, masalah kelaparan, masalah narkotika, masalah hak-hak asasi manusia dipandang sebagai masalah yang bersifat global persoalan-persoalan yang menyangkut nasib seuruh umat manusia.

Masalah pelanggaran hak-hak asasi manusia dimanapun terjadi akan disoroti oleh seluruh dunia. Globalisasi ini dimungkinkan oleh perkembangan yang pesat dalam teknologi informasi. Informasi-infomasi yang penting dengan cepat menyebar ke seluruh dunia berkat teknologi komunikasi yang canggih. Salah satu akibat dari globalisasi adalah bahwa kehidupan ekonomi menjadi lebih terpadu, lebih terintegrasikan. Ekonomi Indonesia telah menjadi bagian ekonomi dunia.Ini berarti bahwa Indonesia menjadi bagia dari suatu pasar global. Dimana barang, jasa, modal serta tenaga kerja berlalu lintas secara bebas. Salah satu akibat dari kenyataan ini adalah bahwa tenaga kerja Indonesia harus bersaing melawan tenaga kerja dari Negara-negara lain. Persoalan yang muncul adalah bagaimana kita meningkatkan daya saing dalam segala bidang.

Ciri lain dari kehidupana abad XXI adalah bahwa kemajuan ilmu dan teknologi yang terus melaju dengan cepatnya ini akan mengubah secara radikal situasi dan pasar tenaga kerja. Kemajuan teknologi menyebabkan pekerjaan-pekerjaan tertentu tidak diperlukan lagi dan timbulah perkerjaan-pekerjaan baru yang menuntut kecakapan baru. Contoh sederhana ialah komputer. Dengan masuknya komputer dalam kehidupan kita, maka banyak tukang ketik kehilangan pekerjaan, yang dibutuhkan sekarang adalah operator komputer yang menguasai paling tidak ampat atau lima program. Perubahan yang paling drastis yang ditimbulkan oelh 
teknologi baru adalah perubahan dalam struktur tenaga kerja. Makin tinggi tingkat teknologi produksi yang dipergunakan selama suatu sistem ekonomi, maka makin tinggi pula tingkat pendidikan yang dituntut dari para pekerjanya. Dalam suatu ekonomi yang seluruhnya mempergunakan teknologi tinggi dan teknologi menengah untuk kegiatan prosuksinya tidak akan ada lagi tempat untuk tenaga kasar yang tidak terdidik. Kecendrungan ditahun-tahun yang akan datang sebagai akibat dari globalisasi informasi akan lahir suatu gaya hidup baru yang mengandung ekses-ekses tertentu. Sebagai ilustrasi penyebaran informasi yang sangat cepat tentang obat-obatan yang mengandung narkotika, literature pornografi, penggunaan senjata api serta alat-alat mikroelektronika untuk melakukan tindakan kejahatan, informasi-informasi seperti ini telah mendorong orang melakukan tindakan-tindakan yang merugikan masyarakat. Perubahan yang paling berarti dalam abad globalisasi ialah kemudahan dalam komunikasi, melalui internet misalnya. Orang dapat berkomunikasi tentang apa saja tanpa disensor oleh siapapun. Kemudahan ini banyak menimbulkan manfaat, tetapi juga menimbulkan berbagai mudarat. Misalnya iklan melalui internet jauh lebih menguntungkan dari pada melalui mas media koran atau televisi. Melalui internet berbelanja menjadi jauh lebih mudah dan lebih nyaman. Godaan akan berbelanja menjadi jauh lebih besar, mereka yang tidak kuat menahan diri akan tergelincir dalam gaya hidup yang sangat konsumtif. Permasalahan yang dikaji dalam artikel ini unsur-unsur pendidikan yang sudah diterapkan dan permasalahan apa sajakah yang dihadapi pada masa lalu dan penentuan dasar kebijakan pendidikan sebaiknya yang diterapkan pada era globalisasi. Adapun tujuan penulisan artikel ini (1) untuk mengetahui unsur-unsur pendidikan yang sudah diterapkan dan ermasalahan yanng dihadapi di masa lalu, dan (2) untuk mengetahui penentuan dasar kebijakan pendidikan yang sebaiknya diterapkan pada era globalisasi. Kajian ini diharapkan dapat memberikan manfaat, diantaranya adalah dengan memahami unsur-unsur pendidikan yang diterapkan di masa lalu, kendala yang dihadapi pada masa lalu dapat dijadikan dasar dalam menentukan arah kebijakan pendidikan di era globalisasi. Metode

Artikel ini menggunakan metode kualitatif, dimana artikel ini menjelaskan mengenai unsur-unsur pendidikan yang sudah diterapkan pada masa lalu, permasalahan yanng dihadapi di masa lalu, dan penentuan dasar kebijakan pendidikan yang sebaiknya diterapkan pada era globalisasi.

\section{Metode}

Kajian ini berbasis pada survei lapangan secara empiris dan analisis data sekunder secara teoritis dari kondisi pendidikan di era globalisasi.

\section{Hasil dan pembahasan Unsur-unsur pendidikan}

Untuk mencapai kualitas pembelajaran yang berkualitas perlu dipahami unsur-unsur pendidikan. Unsur-unsur pendidikan terdiri dari peserta didik, pendidik, interaksi edukatif antara peserta didik dan pendidik, materi/ isi pendidikan (kurikulum), konteks yang mempengaruhi pendidikan, alat dan metode, perbuatan pendidik, dan evaluasi dan tujuan pendidikan.

\section{1) Peserta Didik}

Peserta didik berstatus sebagai subjek didik. Pandangan modern cenderung menyebut demikian oleh karena peserta didik (tanpa pandang usia) adalah subjek atau pribadi yang otonom, yang ingin diakui keberadaannya. Selaku pribadi yang memiliki ciri khas dan otonomi, ia ingin mengembangkan diri (mendidik diri) secara terus menerus guna memecahkan masalahmasalah hidup yang dijumpai sepanjang hidupnya.

Peserta didik sebagai subyek pembelajaran merupakan individu aktif dengan berbagai karakteristiknya, sehingga dalam proses pembelajaran terjadi interaksi timbal balik, baik antara guru dengan siswa maupun antara siswa dengan siswa. Oleh karena itu, salah satu dari kompetensi pedagogik yang harus dikuasai guru adalah memahami karakteristik dan perkembangan kognitif anak didiknya, sehingga tujuan pembelajaran, materi yang disiapkan, 
dan metode yang dirancang untuk menyampaikannya benar-benar sesuai dengan karakteristik siswanya.

Kognitif atau pemikiran adalah istilah yang digunakan oleh ahli psikologi untuk menjelaskan semua aktivitas mental yang berhubungan dengan persepsi, pikiran, ingatan dan pengolahan informasi yang memungkinkan seseorang memperoleh pengetahuan, memecahkan masalah, dan merencanakan masa depan, atau semua proses psikologis yang berkaitan bagaimana individu mempelajari, memperhatikan, mengamati, membayangkan, memperkirakan, menilai dan memikirkan lingkungannya.

Adapun tahap-tahap perkembangan kognitif peserta didik menurut Piaget (Crain, 2007) yaitu (1) tahap sensori motor (0-2 tahun), pada tahap ini seorang anak akan belajar untuk menggunakan dan mengatur kegiatan fIsik dan mental menjadi rangkaian perbuatan yang bermakna; (2) tahap pra-operasional (2-7 tahun), pada tahap ini seorang anak masih sangat dipengaruhi oleh hal-hal khusus yang didapat dari pengalaman menggunakan indera, sehingga ia belum mampu untuk melihat hubungan-hubungan dan menyimpulkan sesuatu secara konsisten; (3) tahap operasional konkret (7-11 tahun), pada tahap ini anak sedang menempuh pendidikan di sekolah dasar. Di tahap ini, seorang anak dapat membuat kesimpulan dari suatu situasi nyata atau dengan menggunakan benda konkret, dan mampu mempertimbangkan dua aspek dari suatu situasi nyata secara bersama-sama (misalnya, antara bentuk dan ukuran); dan tahap operasional formal (lebih dari 11 tahun), pada tahap ini kegiatan kognitif seseorang tidak mesti menggunakan benda nyata.

Karakteristik anak didik ditentukan juga oleh perkembangan fisik peserta didik, perkembangan social emosional peserta didik, dan perkembangan moral peserta didik. Menurut Kuhlen dan Thompson (Crain, 2007) mengemukakan bahwa perkembangan fisik individu meliputi empat aspek, yaitu (a) otot-otot, yang mempengaruhi perkembangan kekuatan dan kemampuan motorik; (b) syaraf yang sangat memengaruhi perkembangan kecerdasan dan emosi; (c) kelenjar endokrin, yang menyebabkan munculnya pola-pola tingkah laku baru, seperti pada usia remaja berkembang perasaan senang untuk aktif dalam suatu kegiatan, yang sebagian anggotanya terdiri atas lawan jenis; dan (d) struktur fisik/tubuh, yang meliputi tinggi, berat, dan proporsi. Perkembangan fisik meliputi perubahan-perubahan dalam tubuh (seperti : pertumbuhan otak, sistem saraf, organ-organ indrawi, pertambahan tinggi dan berat, hormon, dan lain-lain), dan perubahan-perubahan dalam cara individu dalam menggunakan tubuhnya (seperti perkembangan keterampilan motorik dan perkembangan seksual), serta perubahan dalam kemampuan fisik (seperti penurunan fungsi jantung, penglihatan, dan sebagainya).

Perkembangan sosial adalah pencapaian kematangan dalam hubungan atau interaksi sosial. Dapat juga diartikan sebagai proses belajar untuk menyesuaikan diri dengan normanorma kelompok, tradisi dan moral agama. Sedangkan emosi merupakan faktor dominan yang mempengaruhi tingkah laku individu, dalam hal ini termasuk pula perilaku belajar. Emosi dibedakan menjadi dua, yakni emosi positif dan emosi negatif. Emosi positif seperti perasaan senang, bergairah, bersemangat, atau rasa ingin tahu yang tinggi akan mempengaruhi individu untuk mengonsentrasikan dirinya terhadap aktivitas belajar. Emosi negatif sperti perasaan tidak senang, kecewa, tidak bergairah, individu tidak dapat memusatkan perhatiannya untuk belajar, sehingga kemungkinan besar dia akan mengalami kegagalan dalam belajarnya. Pada masa remaja, tingkat karakteristik emosional akan menjadi drastis tingkat kecepatannya. Gejala-gejala emosional para remaja seperti perasaan sayang, cinta dan benci, harapan-harapan dan putus asa, perlu dicermati dan dipahami dengan baik. Sebagai pendidik. kita harus mengetahui setiap aspek yang berhubungan dengan perubahan tingkah laku dalam perkembangan remaja, serta memahami aspek atau gejala tersebut sehingga kita bisa melakukan komunikasi yang baik dengan remaja.

Kecerdasan moral ditandai dengan kemampuan seorang anak untuk bisa menghargai dirinya sendiri maupun diri orang lain, memahami perasaan terdalam orang-orang di sekelilingnya, mengikuti aturan-aturan yang berlaku, semua ini merupakan kunci keberhasilan bagi seorang anak di masa depan. Suasana damai dan penuh kasih sayang dalam keluarga, contoh-contoh nyata berupa sikap saling menghargai satu sama lain, ketekunan dan keuletan menghadapi kesulitan, sikap disiplin dan penuh semangat, tidak mudah putus asa, lebih banyak 
tersenyum daripada cemberut, semua ini memungkinkan anak mengembangkan kemampuan yang berhubungan dengan kecerdasan kognitif, kecerdasan emosional maupun kecerdasan moralnya.

Teori Kohlberg (Crain, 2007) telah menekankan bahwa perkembangan moral didasarkan terutama pada penalaran moral dan berkembang secara bertahap yaitu (1) penalaran prakovensional, pada tingkat ini anak tidak memperlihatkan internalisasi nilai-nilai moral, penalaran moral dikendalikan oleh imbalan (hadiah) dan hukuman ekternal; (2) penalaran konvensional; dan (3) penalaran pascakonvensional, tingkat tertinggi dari teori perkembangan moral Kohlberg. Pada tingkat ini, moralitas benar-benar diinternalisasikan dan tidak didasarkan pada standar-standar orang lain. Seorang mengenal tindakan moral alternatif, menjajaki pilihanpilihan, dan kemudian memutuskan berdasarkan suatu kode moral pribadi.

\section{2) Pendidik}

Pendidik ialah orang yang bertanggung jawab terhadap pelaksanaan proses pendidikan dengan sasaran peserta didik. Pendidik harus memiliki kewibawaan (kekuasaan batin mendidik) dan menghindari penggunaan kekuasaan lahir (kekuasaan yang semata - mata didasarkan kepada unsur wewenang jabatan). Kewibawaan dimiliki oleh mereka yang sudah dewasa. Yang dimaksud adalah kedewasaan rohani yang ditopang kedewasaan jasmani. Kedewasaan jasmani tercapai bila individu telah mencapai puncak perkembangan jasmani yang optimal. Kedewasaan rohani tercapai bila individu telah memiliki cita - cita hidup dan pandangan hidup yang tetap.

Pendidik menurut (Sudhita, 2014) harus memiliki persyaratan antara lain jujur, bertakwa kepada Tuhan Yang Maha Esa, tidak tercela dan tidak pernah berurusan dengan kepolisian karena tindakan kriminal, sehat jasmani dan rohani, memiliki kualifikasi pendidikan tertentu, mampu melaksanakan kompetensi pendidik dan memiliki sertifikat pendidik.

\section{3) Interaksi edukatif antara peserta didik dan pendidik}

Interaksi edukatif pada dasarnya adalah komunikasi timbal balik antar peserta didik dengan pendidik yang terarah kepada tujuan pendidikan, dimana ketika proses belajaran diruangan sedang berlangsung diharapkan antara pendidik dan murid adalah menjadi partner yang saling berargumen logis guna mendapatkan suasana belajar yang efektif. Ketika pendidik memberi bahan ajar berupa materi pelajaran dan contoh-contoh. Diharapkan respon yang baik dari para peserta didik, baik dari persiapan sebelum pembelajaran dimulai maupun ketika terlaksananya pendidikan tersebut. Saling menghargai juga akan sangat membantu keberhasilan pembelajaran saat itu, pendidik ingin dihargai dan peserta didik juga ingin mendapat perlakuan yang santun pula.

4) Materi/isi pendidikan (Kurikulum)

Dalam Sistem Pendidikan KKNI, perlu disesuaikan antara standar kompetensi (profil lulusan) dengan Capaian pembelajaran yang diharapkan dari satu program studi. Capaian pembelajaran dirinci kedalam capaian pembelajaran sikap, pengetahuan, ketrampilan umum dan ketrampilan khusus.

Dalam sistem pendidikan persekolahan, materi telah diramu dalam kurikulum yang disajikan sebagai sarana pencapaian tujuan. Materi ini salah satunya meliputi materi inti maupun muatan lokal. Materi inti bersifat nasional yang mengandung misi pengendalian dan persatuan bangsa. Muatan lokal misinya adalah mengembangkan kebhinekaan kekayaan budaya sesuai dengan kondisi lingkungan.

Standar Nasional pendidikan tinggi (Undang-undang No 20 2003) terdiri dari standar kompetensi lulusan, standar isi pembelajaran, standar proses pembelajaran, standar penilaian pembelajaran, standar dosen dan tenaga kependidikan, standar sarana dan prasarana pembelajaran, standar pengelolaan pembelajaran dan standar pembiayaan pembelajaran. Pada perguruan tinggi, standar untuk mencapai kompetensi lulusan dituangkan dalam kurikulum. Kurikulum terdiri dari sekelompok mata kuliah yangwajib ditempuh oleh mahasiswa untuk mencapai kompetensi yang ditetapkan. Mata kuliah terdiri dari mata kuliah umum dan mata kuliah keahlian yaitu keahlian utama dan keahlian khusus. 


\section{5) Konteks Yang Mempengaruhi Pendidikan}

Konteks yang mempengaruhi pendidikan antara lain alat dan metode. Alat dan metode diartikan sebagai segala sesuatu yang dilakukan ataupun diadakan dengan sengaja untuk mencapai tujuan pendidikan. Alat pendidikan media sosial, misalnya IT (Internet Technology), Hand Phone, Televisi, Radio dan lain-lain. Metode pendidikan dibedakan menjadi dua, yaitu (a) yang bersifat preventif, yaitu mencegah terjadinya hal-hal yang tidak dikehendaki misalnya larangan, pembatasan, peringatan bahkan juga hukuman, dan (b) yang bersifat kuratif, yaitu memperbaiki, misalnya ajakan, contoh, nasihat, dorongan, pemberian kepercayaan, saran, penjelasan, bahkan juga hukuman.

\section{6) Perbuatan Pendidik}

Perbuatan pendidik merupakan kegiatan yang dilakukan oleh pendidik ketika menghadapi peserta didik. Tata cara dan sikap seorang pendidik dalam penyampaian pelajaran juga menunjang pekembangan peserta didik, pendidik harus menghindari sikap menekan mental peserta didik, karena hal ini sangat berpengaruh besar terhadap pendirian, mental, serta perkembangan pengetahuan peserta didik.

\section{7) Tempat Pendidikan berlangsung (lingkungan pendidikan)}

Lingkungan pendidikan berpengaruh juga pada tercapainya tujuan pendidikan. Lingkungan belajar meliputi sarana dan prasarana belajar, seperti ruangan kelas yang memadai, tersedianya ruangan untuk pratikum, kenyamanan dalam belajar (lingkungan luar tidak berisik).

\section{8) Evaluasi dan tujuan pendidikan}

Evaluasi dan tujuan pendidikan merupakan sikap mengulas kembali pelajaran-pelajaran yang sudah dipelajari dalam bentuk latihan dan tugas-tugas. Sehingga materi-materi pelajaran tetap melekat dalam diri peserta didik. Tujuannya adalah membangkitkan, memicu, dan menyegarkan kembali materi-materi yang telah dibahas sebelumnya, agar peserta didik semakin mantap dalam menguasai pelajaran tersebut.

\section{Unsur-Unsur Pendidikan Yang Sudah Diterapkan dan Permasalahan Yang Terjadi Pada Masa Lalu}

Indonesia pernah mengalami masa penjajahan, baik yang pada masa penjajahan Belanda maupun masa penjajahan Jepang. Sehingga, tidak mengherankan apabila pengaruhnya sangat kuat dalam segala bidang, baik di bidang politik, ekonomi, maupun militer. Perkembangan unsur-unsur pendidikan jaman penjajahan pada VOC (Verenigde Oost-Indische Compagnie). VOC merupakan kumpulan dagang untuk mengeruk keuntungan yang besar, lama kelamaan membentuk koloni dan benteng dan memperluas daerah jajahan. Sekolah-sekolah pada jaman VOC, kurikulumnya berkaitan dengan gereja untuk menyebarkan agama kristen. VOC dibubarkan tgl 31 Desember 1899. Pemerintah jajahan yang baru membuat sistem tanam paksa, suatu eksploitasi besar-besaran sehingga mendorong penjajah untuk memberikan pendidikan kepada anak-anak Indonesia untuk mendidik pegawai perkebunan pemerintah.

Ada enam ciri utama dari politik dan praktik pendidikan kolonial Belanda, yaitu: (1) gradualisme (perbedaan perlakuan antara pribumi dan warga Belanda), (2) dualisme (antara anak Belanda dan pribumi), (3) kontrol pusat yang ketat, (4) pendidikan pegawai sebagai peranan sekolah yang utama, (5) prinsip konkordansi (menyamakan sekolah di Indonesia dan Belanda), dan (6) tidak ada perencanaan pendidikan yang sistematis.

Pada masa pendudukan Jepang, Sistem penggolongan dihapuskan oleh Jepang. Rakyat menjadi alat kekuasaan Jepang untuk kepentingan perang. Pendidikan pada masa kekuasaan Jepang memiliki landasan idiil hakko Iciu yang mengajak bangsa Indonesia berkerjasama untuk mencapai kemakmuran bersama Asia raya. Pelajar harus mengikuti latihan fisik, latihan kemiliteran, dan indoktrinasi yang ketat. Pada tahun 1942-1945, masa pendudukan Jepang memberikan corak yang berarti pendidikan di Indonesia. Tidak lama setelah berkuasa, Jepang segera menghapus sistem pendidikan warisan Belanda yang didasarkan atas penggolongan menurut bangsa dan status sosial. Tanpa membedakan status social mulai di buka tingkat 
sekolah terendah adalah Sekolah Rakyat (SR), Sekolah Menengah Pertama (SPM) selama tiga tahun, Sekolah Menengah Tinggi (SMT) selama tiga tahun. Sekolah dikejuruan juga di kembangkan, yaitu Sekolah Pertukangan, Sekolah Teknik Menengah, Sekolah Pelayaran, Sekolah Pelayaran dan Sekolah Pelayaran Tinggi. Ditingkatkan pendidikan tinggi, pemerintah pendudukan Jepang mendirikan Sekolah Tinggi Kedokteran (Ika Dai Gakko) di Jakarta dan Sekolah Tinggi Teknik di Bandung.

Perubahan lain yang berarti bagi Indonesia dikemudian hari ialah bahasa Indonesia menjadi bahasa pengantar pertama di sekolah-sekolah dan kantor-kantor pemerintahan, dan bahasa pengantar kedua adalah Jepang. Sejak saat itu, bahasa Indonesia berkembang pesat sebagai bahasa pengantar dan bahasa komunikasi ilmiah. Tujuan pendidikan pada zaman Jepang diarahkan untuk mendukung pendudukan Jepang dengan menyediakan tenaga kerja kasar secara Cuma-Cuma yang dikenal dengan romusha. Di sekolah, para siswa mengikuti latihan fisik, baris berbaris meniru tentara Dai Nippon, latihan kemiliteran disertai indoktrinasi yang intinya kesetiaan penuh pada Kaisar Jepang. Pemuda-pemuda yang menapak dewasa dijadikan romusha dan sebagian direkrut untuk menjadi tentara. Tujuan pendidikan lebih ditekankan kepada dihasilkannya tenaga buruh kasar secara cuma-cuma dan prajurit-prajurit untuk keperluan peperangan Jepang.

Pendidikan dalam rangka perjuangan kemerdekaan ditandai oleh munculnya gerakan pendidikan yang dipelopori oleh Muhammadiyah, Perguruan Taman Siswa, INS Kayutanam, Pendidikan Ma'arif dan perguruan islam lainnya. Tujuan pendidikan pada masa perjuangan adalah : (1) mendidik anak kearah hidup yang merdeka/mandiri, (2) menanamkan kepercayaan pada diri sendiri, kemauan keras, berani bertanggung jawab; (3) membiayai sendiri, cari sendiri dan kerjakan sendiri; (4) mengembangkan anak secara harmonis: perasaan, kecerdasan, dan keterampilan; (5) mengembangkan sikap sosial; (6) pendidikan sesuai bakat anak, dan (7) bekerja menurut kebutuhan lingkungan.

Pada jama orde lama terdapat persoalan yang akut saat itu adalah bagaimana mengatur jumlah penduduk yang masih buta huruf tidaklah sedikit. Kebijakan pendidikan pada jaman orde lama antara lain (1). tiap-tiap warga negara berhak mendapat pengajaran, (2) memilih pengajaran yang akan diikuti, adalah bebas, dan (3) mengajar adalah bebas, dengan tidak mengurangi pengawasan penguasa yang di lakukan terhadap itu menurut peraturan unduangundang. Salah satu hal yang menentukan orde lama berkaitan dengan kebijakan-kebijakan pendidikannya adalah, terciptanya undang-undang No.4 tahun 1950, Tentang dasar-dasar pendidikan dan pengajaran di sekolah untuk Seluruh Indonesia. Tujuan pendidikan dan pengajaran ialah membentuk manusia susila yang cakap, dan warga negara yang demokratis serta bertanggung jawab tentang kesejahtraan masyarakat dan tanah air. Pendidikan dan pangajaran berdasar atas asas-asas yang termasuk dalam pancasila, Undang-undang dasar negara republik indonesia, dan atas kebudayaan kebangsaan indonesia. Sementara, bahasa pengantar yang di pakai dalam proses belajar mengajar adalah bahasa indonesia.Penggunaan bahasa indonesia sebagai bahasa pengantar dalam proses belajar mengajar ini diatur pada bab IV pasal 5, yaitu Bahasa indonesia sebagai bahasa persatuan adalah bahasaa pengantar di sekolah-sekolah diseluruh repoblik indonesia.

Pada pada masa pemerintahan orde baru pembangunan di bidang pendidikan memiliki dua fungsi dalam keseluruhan kerangka pembangunan ekonomi yaitu (1) mengusahakan agar kesempatan mendapatkan pendidikan menjadi terjangkau oleh semua masyarakat, (2) meningkatkan secara berangsur-angsur kualitas sumber daya manusia Indonesia melalui pendidikan yang bermutu. Untuk meningkatkan mutu pendidikan pada masa Orde Baru dilaksanakan melalui (1) peningkatan mutu pendidikan kejuruan ,2) peningkatan mutu pendidikan umum, (3) pembaharuan kurikulum, dan (4) pembangunan di bidang pendidikan Guru pra jabatan.

Pendidikan pada zaman reformasi mengalami suatu perkembangan yang pada dasarnya lebih maju daripada pendidikan pada zaman orde baru. Pendidikan pada zaman reformasi mengutamakan pada perkembangan peserta didik yang lebih terfokus pada pengelolaan masing - masing daerah (otonomi pendidikan). Dalam hal tenaga kependidikan diberlakukan suatu kualifikasi profesional untuk lebih meningkatkan mutu pendidikan Indonesia. Sedangkan sarana 
dan prasarana juga sudah mengalami suatu peningkatan yang baik. Namun daripada hal tersebut pendidikan yang ada di Indonesia masih belum mengalami suatu pemerataan. Ini terlihat dari adanya beberapa sekolah -sekolah terutama di daerah pedalaman masih terdapat keterbatasan dalam berbagai aspek penyelenggaraannya. Dinamika sosial politik Indonesia yang juga berdampak pada perubahan kurikulum merupakan suatu bentuk penyempurnaan dalam bidang pendidikan untuk meningkatan mutu pendidikan di Indonesia. Sejarah pendidikan di era reformasi terkait perubahan kurikulum dari KBK, KTSP hingga K-13 yang akhirnya kembali ke KTSP dan adanya UU Sistem Pendidikan Nasional (UU Sisdiknas) PP. No.20 tahun 2003 yang membawa dampak pembaharuan di bidang pendidikan seperti, adanya sertifikasi guru dan dosen, lembaga-lembaga yang mengatur jalannya proses pendidikan dan akreditasi (BSNP dan BAN-PT), adanya dana BOS, program SM3-T, serta program-program lainnya.

Kurikulum Berbasis Kompetensi (KBK) dapat diartikan sebagai suatu konsep kurikulum yang menekankan pada pengembangan kemampuan melakukan (kompetensi) tugas-tugas dengan standar performansi tertentu, sehingga hasilnya dapat dirasakan oleh peserta didik, berupa penguasaan terhadap seperangkat kompetensi tertentu (Mulyasa, 2006) KTSP yang merupakan penyempurnaan dari Kurikulum 2004 (KBK) adalah kurikulum operasional yang disusun dan dilaksanakan di masing-masing satuan pendidikan/sekolah.

Menurut Muslich $(2007,12)$ KTSP terdiri dari tujuan pendidikan tingkat satuan pendidikan, struktur dan muatan kurikulum tingkat satuan pendidikan, kalender pendidikan, dan silabus. Silabus adalah rencana pembelajaran pada suatu dan/atau kelompok mata pelajaran/tema tertentu yang mencakup standar kompetensi, kompetensi dasar, materi pokok/pembelajaran, kegiatan pembelajaran, indikator, penilaian, alokasi waktu, dan sumber/bahan/alat belajar. Silabus merupakan penjabaran standar kompetensi dan kompetensi dasar ke dalam materi pokok/pembelajaran, kegiatan pembelajaran, dan indikator pencapaian kompetensi untuk penilaian. Pelaksanaan penyusunan kurikulum 2013 adalah bagian dari melanjutkan pengembangan Kurikulum Berbasis Kompetensi (KBK) yang telah dirintis pada tahun 2004 dengan mencakup kompetensi sikap, pengetahuan, dan keterampilan secara terpadu, sebagaimana amanat UU 20 tahun 2003 tentang Sistem Pendidikan Nasional pada penjelasan pasal 35, di mana kompetensi lulusan merupakan kualifikasi kemampuan lulusan yang mencakup sikap, pengetahuan, dan keterampilan sesuai dengan standar nasional yang telah disepakati. Dengan kendala yang ditemui dalam pelaksanaan K-13, akhirnya sekolahsekolah yang baru menjalan K-13 kembali menggunakan KTSP, sampai dinyatakan bahwa semua satuan pendidikan (sekolah) siap menjalankan K-13.

\section{Penentuan Dasar Kebijakan Pendidikan Yang Sebaiknya Diterapkan Pada Era Globalisasi}

Dengan memahami kondisi pendidikan di masa lalu dapat memperjelas pemahaman pendidikan di Negara ini saat sekarang. Sistem pendidikan yang kita miliki sekarang adalah hasil perkembangan pendidikan yang tumbuh dalam sejarah pengalaman bangsa kita yang telah lewat. Bila kita lihat jauh ke belakang, pendidikan yang kita kenal sekarang ini sebenarnya merupakan "adopsi" dari berbagai model pendidikan di masa lalu.Informasi mengenai bagaimana model pendidikan di masa prasejarah masih belum dapat terekonstruksi dengan sempurna. Namun bisa diasumsikan "media pembelajaran" yang ada pada masa itu berkaitan dengan konteks sosial yang sederhana. Terutama berkaitan dengan adaptasi terhadap lingkungan di kelompok sosialnya.

Pendidikan di masa depan akan banyak mendapat tantangan, terutama tantangan globalisasisi. Untuk mengatasi permasalahan tantangan globalisasi, menurut Buchori (2001) setiap dunia pendidikan hendaknya mempersiapkan peserta didik untuk mengarungi kehidupan di masa depan. Dengan mengisitilahkan antisipatoris beliau mengingatkan bahwa dalam menyelenggarakan pelayanan pendidikan, kita hendaknya melihat jauh ke depan, memikirikan apa yang akan dihadapi anak cucu kita di masa yang akan datang, tidaklah tepat jika kita hanya memikirkan kebutuhan generasi sekarang, kita harus melihat dua generasi yang akan datang.

Pemikiran Buchori untuk menghadapi masa depan antara lain: (1) transformasi Pendidikan sekolah menuju Abad XX1, dan (2) perlu memahami makna pentingnya modernisasi 
dan modernitas. Setiap sistem pendidikan selalu berusaha memahami zamannya dan berusaha pula memenuhi tuntutan-tuntutannya. Setiap pendidikan yang dewasa selalu berusaha mempersiapkan masyarakat yang dilayaninya mengembangkan wawasan-wawasan baru untuk mengakomodasikan perubahan-perubahan yang tampak akan datang, sangat diperlukan suatu intraksi antar sekolah dan masyarakat. Transformasi pendidikan adalah perubahan wajah dan watak yang terjadi pada sistem pendidikan sebagai akibat dari intraksi

Untuk memahami makna pentingnya modernisasi dan modernitas. Kita hanya dapat membuat pilihan mengenai gaya hidup yang akan kita kembangkan bersasarkan kemajuankemajun nyata dalam modernisasi kalau kita benar-benar paham akan makna dan latar belakang dari setiap kemajuan itu. Oleh karena itu sejarah modernisasi dan modernitas merupakan suatu keharusan. Persoalan yang dihadapi oleh semua Negara baik yang maju dan yang sedang berkembang ialah bahwa kita menjalani modernisasi tanpa banyak tahu akan ujung pangkal modernisasi itu sendiri, kita merasa sebagai manusia modern tanpa memahami makna modernitas yang selanjtnya menjadi sumber dari segenap penyalahgunaan modernisasi dan modernitas.

Kehidupan modern yang penuh dengan berbagai ketimpangan, pertentangan, dan kemajuan dapat membuat manusia kehilangan maknanya dalam hidup. Untuk menghindari hal ini dianjurkan suatu program pendidikan umum yang memberikan kemampuan kepada siswa untuk menangkap berbagai jenis makna yang terdapat dalam pendidikan.

Menurt Phenix dalam kehidupan terdapat enam jenis wilayah makna yaitu symbolic, empirics, esthetics,synnoutics, ethic, synoptics (Buchori, 2001, p.32) Untuk memahami makna di wilayah symbolic harus diberikan pendidikan dalam bahasa, matetmatika dan nondiscousius symboli, untuk memahami berbagai makan yang ada di wilayah empirics harus diberikan pendidikan tentang lingkungan fisik, fisika, kimia, biologi, lingkungan social dan budaya. Untuk memberikan kemampuan memahami makna dalam wilayah esthetics biasanya diajarkan seni seni suara, sastra, visual arts, dan seni gerak. Untuk mmberikan makan dalam wilayah synoeitics yang perlu diajarkan adalah drama dan pembahsan film atau jenis-jenis cerita yang lain. Untik dapat memahami makna yang terletak dalam wilayah ethics perlu ditanamkan kesadaran untuk menghormati dan mematuhi secara sukarela norma-norma yang ada. Untik memahami makna yang terdapat dalam wilayah synoptic, mata pelajaran yang harus diajarkan adalah sejarah, filsafat dan agama. Menurut rancangan makna ini sejarah adalah suatu pelajaran yang diberikan kepada para siswa untuk memahami mengapa suatu masyarakat dalam waktu tertentu di masa lampau mengambil keputusan tertentu dalam menghadapi persoalan tertentu. Jadi dalam rancangan pendidikan ini ialah memahami bukan menilai. Para siswa secara berangsur-angsur dibimbing untuk menangkap makna apa yang terdapat dibalik yang terlihat atau terasa secara fisik, para siswa dilatih untuk memahami makna dari makna yang kecil sampai makna yang besar yaitu makna kehidupan itu sendiri

Kebijakan pendidikan dalam era informasi saat ini para siswa dipersiapkan untuk menghadapi tiga tugas kehidupan yaitu untuk dapat hidup, untuk mengembangkan kehidupan yang bermakna, dan untuk turut memuliakan kehidupan. Kehidupan yang bermakna adalah hasil dari pengenalan diri sendiri, dan pengetahuan mengenai bagaimana menyatakan jati diri secara berarti dalam berbagai lingkungan kehidupannya. Kehidupan pribadi yang bermakna ini dapat dituangkan dalam berbagai bentuk. Untuk mempersiapkan para siswa kita mengenali dirinya secara baik dan untuk memahami misi hidupnyan secara baik pula, praktek pengajaran klasikal harus dilanjutkan dengan praktek pendidikan personalia. Cara yang paling baik memberikan kesempatan dan mendorong para siswa untuk memperoleh pengalamanpengamlaman pendidikan non formal dan informal, disamping pendidikan formal yang mereka peroleh dari kurikulum

\section{Simpulan dan saran}

Berdasarkan pembahasan yang telah diuraikan di atas dapat disimpulkan bahwa unsurunsur pendidikan pada setiap pada masa lalu terus-menurus diupayakan perbaikan dan penyempurnaan ke arah yang lebih baik. 
Dasar kebijakan pendidikan yang dapat diterapkan pada masa depan antara lain (1) transformasi Pendidikan sekolah menuju Abad XX1, (2) perlu memahami makna pentingnya modernisasi dan modernitas, (3) kehidupan modern yang penuh dengan berbagai ketimpangan, pertentangan, dan kemajuan dapat membuat manusia kehilangan maknanya dalam hidup, untuk menghindari hal ini dianjurkan suatu program pendidikan umum yang memberikan kemampuan kepada siswa untuk menangkap berbagai jenis makna yang terdapat dalam pendidikan, dan (4) peserta didik perlu lebih ditekankan pendidikan sejarah, sejarah adalah suatu pelajaran yang diberikan kepada para siswa untuk memahami mengapa suatu masyarakat dalam waktu tertentu di masa lampau mengambil keputusan tertentu dalam menghadapi persoalan tertentu. Para siswa secara berangsur-angsur dibimbing untuk menangkap makna apa yang terdapat dibalik yang terlihat atau terasa secara fisik, para siswa dilatih untuk memahami makna dari makna yang kecil sampai makna yang besar yaitu makna kehidupan itu sendiri.

Saran yang dapat dijadikan dasar untuk kemajuan pendidikan ke depan antara lain (1) perlunya memadukan unsur-unsur pendidikan secara terarah, dan (2) perlunya pemahaman makna dalam pendidikan sehingga tujuan pendidikan yang ditetapkan dapat terwujud.

\section{Daftar Rujukan}

Buchori, Muchtar. 2001. Pendidikan Antisipatoris. Yogyakarta: Penerbit Kanisius.

Crain, William. 2007. Teori Perkembangan Konsep dan Aplikasi (Yudi Santoso, Penerjemah). Yogyakarta: Pustka Pelajar.

Departemen Pendidikan Nasional Republik Indonesia. 2003. Undang-Undang Republik Indonesia Nomor 20 Tahun 2003 Tentang Sistem Pendidikan Nasional. Jakarta.

Mulyasa. 2006. Kurikulum Berbasis Kompetensi (Konsep, Karakteristik, dan Implementasi). Bandung: PT Remaja Rosdakarya.

Muslich, Masnur. 2007. Kurikulum Tingkat Satuan Pendidikan Dasar Pemahaman dan Pengembangan. Jakarta : Bumi Aksara.

Sudhita Romi, I W. 2014. Pengantar Pendidikan. Yogyakarta: Graha Ilmu.

Tim Pengembang Undiksha. 2016. Panduan Pengembangan Kurikulum Berbasis Kompetensi Berorientasi KKNI untuk Program Srata 1 dan Diploma III. Singaraja: Undiksha.

Zaifbio. 2010. Ciri-ciri dan Masalah Pendidikan. tresedia pada https://zaifbio.wordpress.com/2010/01/14/ciri-ciri-dan-masala 18 Februari 2018. 